\title{
Food Industry 4.0 Readiness in Hungary
}

\author{
A. S. DEBRENTI ${ }^{1}$, M. HERDON ${ }^{2}$ \\ 1University of Debrecen, Faculty of Economics and Business, debrenti@gmail.com \\ 2University of Debrecen, Faculty of Economics and Business, herdon.miklos@econ.unideb.hu
}

\begin{abstract}
In terms of production value, the food industry is the third-largest in Hungary, the first in Hungary in terms of the number of employees, and the first in Europe in the processing industry, as well as a significant user of resources. The research examined the state of art of digitalization readiness, focusing on I4.0 technologies, which supports the management to operate more efficiently the enterprise and to make better decisions. So the focus was on integrated enterprise information systems, management support systems, business intelligence systems, industry 4.0 technologies, and issues related to their application. The analysis based on an online questionnaire survey the request sent to 4.600 enterprises, the response rate was 5\% which was representative of the branches of production, covered the Hungarian food and beverage manufacturing sectors in 2019. The companies were asked the most critical technologies in development, going towards Industry 4.0. The research tools were LimeSurvey, Mailing List Server, Excel, Power BI (Desktop, Publishing Server to distribute the results). The used analysing methods were making calculations, pivot tables, models, dasboards. We found that a significant portion of businesses, $78 \%$, use mobile devices in the manufacturing process. The three most relevant digital technologies are geolocating (GPS, GNSS), cloud computing, and sensor technology. The current level of digitalization and integration cannot be said to be high, but respondents are very optimistic about expectations. Improvements are expected in all areas in the next 2-3 years in terms of digitalisation and integration. Vertical integration involves, first and foremost, cooperation with partners in the supply chain. Horizontal integration means close, real-time connectivity and collaboration within the company. Unfortunately, between $6 \%$ and $15 \%$ of SMEs (approximately $9 \%$ on average) and large enterprises, 36\% have a digital strategy. According to the survey, the sector needs significant improvement and creating a digitalization strategy.
\end{abstract}

\section{Introduction}

Over the last years, manufacturing companies have to face several challenges, mainly related to the volatility of the demand and the continuously changing requirements, both from the customers and suppliers. In the meantime, new technological roadmaps and suggested interventions in manufacturing systems implemented (Demartini et al., 2018). Tokody (2018) examined whether there is any general or formalized technology that could be equally used in various fields, and which could help to achieve digitalization in everyday life, also in the industry or in manufacturing. Agri-food enterprises operate in a complex and dynamic environment (Wolfert et al., 2010) and facing different challenges, such as financial issues, lack of technical skills and investment in the business, etc. (Zhang, 2012). Pusztai et al. (2019) in their case study examined an assembly line using fuzzy values in business planning. This method can support project managers in building the uncertainty factor in the project planning model. 
Industry 4.0, also known as the Industrial Internet of Things or IIoT, incorporates technology to create a wholly connected industry. It collects information about processes, equipment performance, supplies and orders, and big data aggregates information from suppliers, manufacturers, and customers. Manufacturing digitalization and the growth of big data promises to foster more responsive supply chains and to close gaps between manufacturers and consumers, leading to highly-connected manufacturing operations, mass customization and more sustainable production (Zaki et al. 2017).

The new digital industrial technology or prevalently known as Industry 4.0, was first spoken at the 2011 Hannover Trade Fair in Germany. Ever since, a global race towards intelligent manufacturing observed with the United States, Germany, Japan, and China leading the movement. The term "Industry 4.0" stands for the fourth industrial revolution, headed for automation and data exchanges in the technologies (Heiner et al., 2014; Henning et al., 2013). Although a complete digital food factory seems to have a long way to go, there have been many functions that are embracing the Industry 4.0 technologies. These are Enterprise Resource Planning (ERP), Manufacturing Execution System (MES), Food Quality Assurance, Research and Development, Facilities Management and many more departments available in a typical food enterprise. Rauch et al. (2018) and Khan et al. (2018) provide a comprehensive review of the robotic potential that is foreseen by researchers in designing future food manufacturing plant. Food handling and packaging setup are limited in capacity and output due to manual processing. The review also highlights the possibilities and limitations of introducing these high technology robots in the food sector. Many new horizons in research and development of food robots also highlighted in the upcoming industrial paradigm. Manavalan \& Jayakrishna (2019) reviewed the various aspects of SCM, ERP, IoT and Industry 4.0 and explored the potential opportunities available in IoT embedded sustainable supply chain for Industry 4.0 transformation. Their conceptual framework model formulated from five valuable perspectives of supply chain management namely Business, Technology, Sustainable Development, Collaboration, and Management Strategy. This study improved the criteria that can be assessed by companies to realize the readiness for industry 4.0 transformation. To increase the production efficiency can be supported a lot of ICT based methods. Pusztai et al. (2017) analysed the assembly activities in a small company and improved the processes by using a simulation technique.

Bombaywala \& Riandita (2015) Describe the driving forces for development in food processing and packaging technologies. It is apparent that the food industry is taking steps to integrate external knowledge sources in the innovation process; still, suppliers continue to play a limited strategic role in innovation. This study shows that some barriers to collaboration identified, and they grouped into two types: technical and perspective. Technical factors constitute a lack of technical expertise amongst food manufacturers, requirement for legal framework and difficulty in predicting future needs. Miranda et al. (2019) focus on describing how S3 technologies for the agri-food sector can be developed using a systematic process for new product development (NPD). The main objective of this work is to fill the gap in the current lack of design roadmaps that permit the development of this new generation of products in the context of agri-food 4.0. Since 2011 when it announced, Industry 4.0 has inspired a series of governmental and private programs worldwide (Mogos et al., 2019).

Nevertheless, it is an emerging research field, and academia calls for further explorative research, including on the enablers and inhibitors of Industry 4.0 implementation at a national level. In recent 
years, Industry 4.0-focused approaches have gained importance (Tektüfekci, 2019). Together with electronic trade, a modernist and innovative form of entrepreneurship has started, and automation has become widespread with the use of information technology. Food safety has been fervently discussed throughout the world (Rahmat et al., 2016; Gimenez-Escalante, 2019). Unified three-level blockchain architecture is proposed as a guideline for researchers and industries to identify the potentials of blockchain and adapt, develop, and incorporate this technology with their manufacturing developments towards Industry 4.0 (Lee et al., 2015; Füzesi et al., 2019). Wong et al (2019) investigated the effects of relative advantage, complexity, upper management support, cost, market dynamics, competitive pressure and regulatory support on blockchain adoption for operations and supply chain management among Small-Medium Enterprises (SMEs) in Malaysia

Although the notion of Industry 4.0 or 'smart manufacturing' may have previously had more significant application to perceived high-tech industries such as aerospace and automotive, the opportunities for the food and beverage industry are significant. Organizations will, therefore, need to take a more strategic approach to identify, manage, and treat these new and emerging Industry 4.0 risks in order to protect themselves and their customers. Ourania \& Aspasia (2015) investigated the changes in marketing strategies of 92 Greek food manufacturing companies.

Deciding to transition to Industry 4.0 requires a significant investment in new equipment and employees. Many manufacturers feel unready to replace equipment that still functions well, or replace less-skilled workers with technical professionals. While the food industry may not be completely ready to embrace Industry 4.0, manufacturing trends are moving in that direction (Nichols, 2018; Marsh, 2017).

The "Food Industry Concept of Hungary 2017-2050" approved by the Government gives priority to the development of the food industry. Strengthening innovation, technological change, and digitalisation in the food industry is also crucial for more efficient use of resources, reducing losses, increasing productivity, quality assurance and addressing labour shortages. Experts estimate that $80 \%$ of the food industry's problems could be solved by adapting Industry 4.0 and other digitization technologies already in use in other industries, but most food industry players are unaware of new technologies, while developers are not aware of the industry's problems. On the other hand, business success determined by a series of managerial decisions. With the advancement of information technology solutions, several tools are available to assist with large amounts of data processing, flexible querying, visualization, analysis of relationships and trends, and filtering of business process management information based on a pre-developed operating model to effectively support management decisions. Botos et al. (2018) \& Füzesi et al. (2018) analysed the ICT and ERP usage in the Hungarian agri-food sector.

Industry 4.0 solutions may also provide an appropriate response to industry-wide capacity constraints. Within the manufacturing industry, the food industry is the second-largest source of revenue and output, and the second-largest employer, with almost 90,000 people. Food industry sales exceeded HUF 3,600 billion in 2017, with exports accounting for one-third of this revenue. The sector is growing dynamically, and profits have doubled in the last five years. 
In the food industry, the proliferation of industry 4.0 solutions is hampered by the unique and heterogeneous nature of the industry, its 33 industry sectors and company sizes across industries, and the product lines or products to be manufactured require different development directions and solutions.

\section{The aim of research, methods}

The purpose of the research was to learn about the digitization of the Hungarian food businesses, using the main IT tools and systems used to address the following digital integration elements: IT infrastructure and Internet usage, enterprise management systems, the use and role of decision support and business analytics tools; Industry 4.0 for technology change reviews.

The questions in our survey were the following:

- Which Digital Technologies Contribute to Business Industry 4.0?

- Did analyse business based on the data generated by SMART tools in 2018 ?

- Did analyse business by geolocation data from handheld devices?

- What are the levels of vertical and horizontal integration?

- Has your business a digital strategy?

- Does anyone have responsibilities for the digital transformation of business?

- What is the level of investments related to Industry 4.0?

- What are the benefits of digitalization over the next five years?

The question types were Yes / No, List (Radio), Multiple Choice, Matrix (5 point selection), Date / Time, Matrix (Yes / No / Not sure), Matrix Dual Scale, Short Free Text.

The research tools in the analysing processes are shown in Figure 1. 


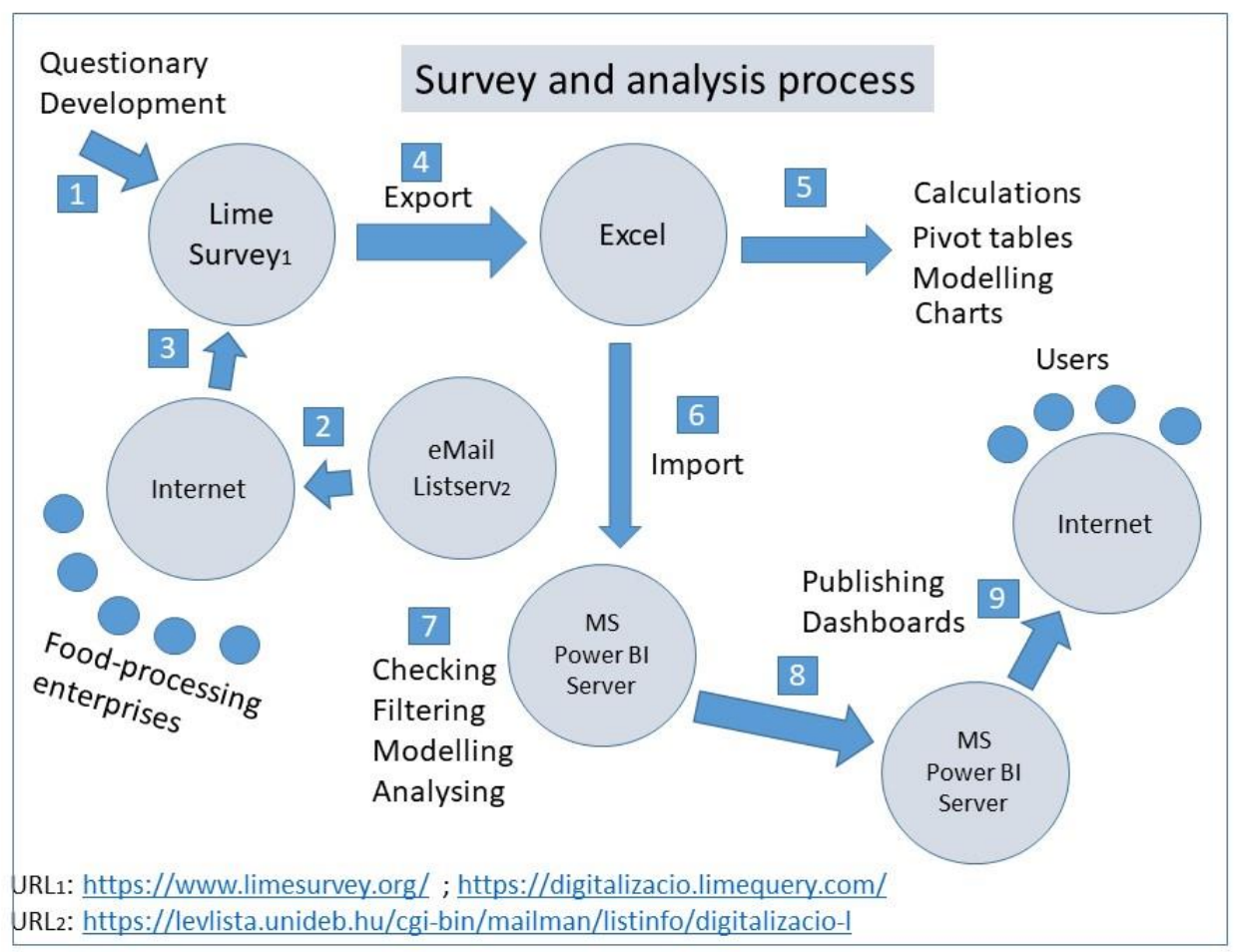

Figure 1. Research tools and processes

Limesurvey is a professional questionnaire engine with a pre-installed environment and database. Once one entered the system, he can create the questionnaire he wants to do by first defining the frame of the questionnaire, then the question groups, and the questions themselves.

The questionnaire produced can contain a wide variety of question types and layouts, among which a conditional relationship can be established. The user can also parameterize the number of respondents to the questionnaire. An introductory and closing text can be added to the question list.

The results of the completed questionnaire are stored in a database, which can be extracted in doc, Xls, Csv, pdf, Html or even SPSS statistical formats. Besides, the application can automatically generate preliminary statistical indicators and diagrams from the results.

The surveyed population consisted of Hungarian food processing companies. During the examination, we tried to obtain a representative sample. Because the sample was sent to all enterprises from the entire population, respondents were randomly selected, so each sampling unit had the same chance of responding (to the sample).

The general requirement for sample selection, as described above, is that the sample is representative of the population from which it was taken, that is, to reflect well the composition and characteristics of the population. So we aimed for a representative sample with the same characteristics as the primary population. The aim was to ensure that the sample population reflects the characteristics of the sample population. Table 1 shows the sample size and degree of representativeness. 


\begin{tabular}{|r|l|r|r|r|}
\hline $\begin{array}{c}\text { Branch } \\
\text { code }\end{array}$ & \multicolumn{1}{|c|}{ Branch } & $\begin{array}{c}\text { Number of } \\
\text { enterprises } \\
\text { B }\end{array}$ & $\begin{array}{c}\text { Number in the } \\
\text { sample } \\
\text { A }\end{array}$ & $\begin{array}{c}\text { Percentage } \\
\text { B/A }\end{array}$ \\
\hline 104 & Manufacture of vegetable and ani & 60 & 7 & $12 \%$ \\
\hline 109 & Production of feed & 100 & 12 & $12 \%$ \\
\hline 105 & Milk Processing & 100 & 11 & $11 \%$ \\
\hline 106 & Manufacture of grain mill product & 100 & 10 & $10 \%$ \\
\hline 101 & Meat Industry & 500 & 38 & $8 \%$ \\
\hline 108 & Manufacture of other food produr & 600 & 44 & $7 \%$ \\
\hline 103 & Processing of fruits and vegetable & 500 & 27 & $5 \%$ \\
\hline 107 & Manufacture of bakery and farina & 1200 & 36 & $3 \%$ \\
\hline 110 & Beverage industry & 1400 & 33 & $2 \%$ \\
\hline
\end{tabular}

Table 1. The survey sample

Considering the size distribution of respondents by size category (Table 2), three-quarters of micro enterprises have sales below HUF 50 million, while the small part of small enterprises are between HUF 100 million and HUF 1 billion, while in the case of medium enterprises Part One has net annual sales of more than HUF 1 billion. 93\% of large companies have sales of over 1 billion HUF.

\begin{tabular}{|l|r|r|r|r|r|}
\hline \multicolumn{1}{|c|}{$\begin{array}{c}\text { Annual net sales / } \\
\text { Company size }\end{array}$} & Micro- & Small- & Middle- & Large- & $\begin{array}{c}\text { All } \\
\text { enterprises }\end{array}$ \\
\hline$<2$ million HUF & 9 & 1 & 0 & 0 & 10 \\
\hline $2-10$ million HUF & 17 & 0 & 1 & 0 & 18 \\
\hline 10 and 50 million HUF & 22 & 3 & 1 & 0 & 26 \\
\hline $50-100$ million HUF & 8 & 6 & 1 & 0 & 15 \\
\hline $100-200$ million HUF & 3 & 21 & 2 & 0 & 26 \\
\hline $200-500$ million HUF & 6 & 22 & 1 & 0 & 29 \\
\hline 500 million HUF and 1 billion HUF & 0 & 21 & 4 & 1 & 26 \\
\hline$>1$ billion HUF & 0 & 13 & 28 & 14 & 55 \\
\hline \multicolumn{1}{|c|}{ Altogether } & $\mathbf{6 5}$ & $\mathbf{8 7}$ & $\mathbf{3 8}$ & $\mathbf{1 5}$ & $\mathbf{2 0 5}$ \\
\hline
\end{tabular}

Table 2. The sample by Annual Revenue / Company size

\section{Industry 4.0 digitalization technologies and business readiness}

\subsection{Opinions on digitization technologies}

The term Industry 4.0, referring to the Fourth Industrial Revolution, is a collective name for a period of the ever closer intertwining of information technology and automation, and thus a fundamental change in manufacturing methods. It is reshaping the entire production and supply chain, which represents a significant paradigm shift for industrial companies in their strategy.

To implement Industry 4.0, you need tools that generate data, creating big data. With the help of a questionnaire, we examined the contribution of different digital devices and technologies to the digitalization of the surveyed enterprises and the development of the Industry 4.0 concept.

As you can see in Figure 2 below, a significant portion of businesses, 78 \%, use mobile devices during the manufacturing process. The next three most relevant digital technologies are positioning (GPS, GNSS), cloud computing, and sensor technology. 


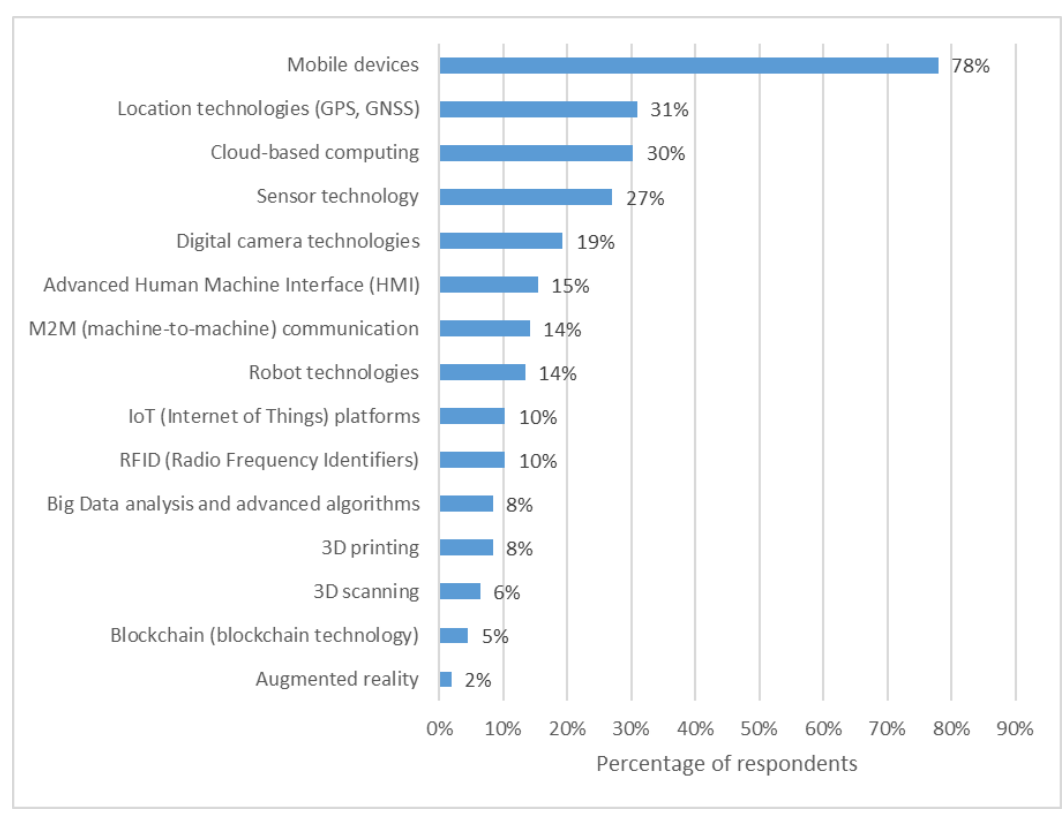

Figure 2. Contribution of digital technologies to Industry $4.0(N=155)$

The five most important technologies are mobil devices apps, gelocation technologies, cloud-based computung, sensor technologies and using digital camera. But using these technolgies are differs according to the sises of enterprises (Figure 3). There is no large difference in using mobile devices, bat there are large fifferences in using geolocation technologies, cloud computing and sensor technologies. Analysing these technologies by branches the preferred technologies rate is different. This is obviously due to the different production characteristics of the different braches and the differences in the production technologies. A more in-depth analysis of differences would obviously require a more detailed examination of the production technologies of the braches (Table 3).

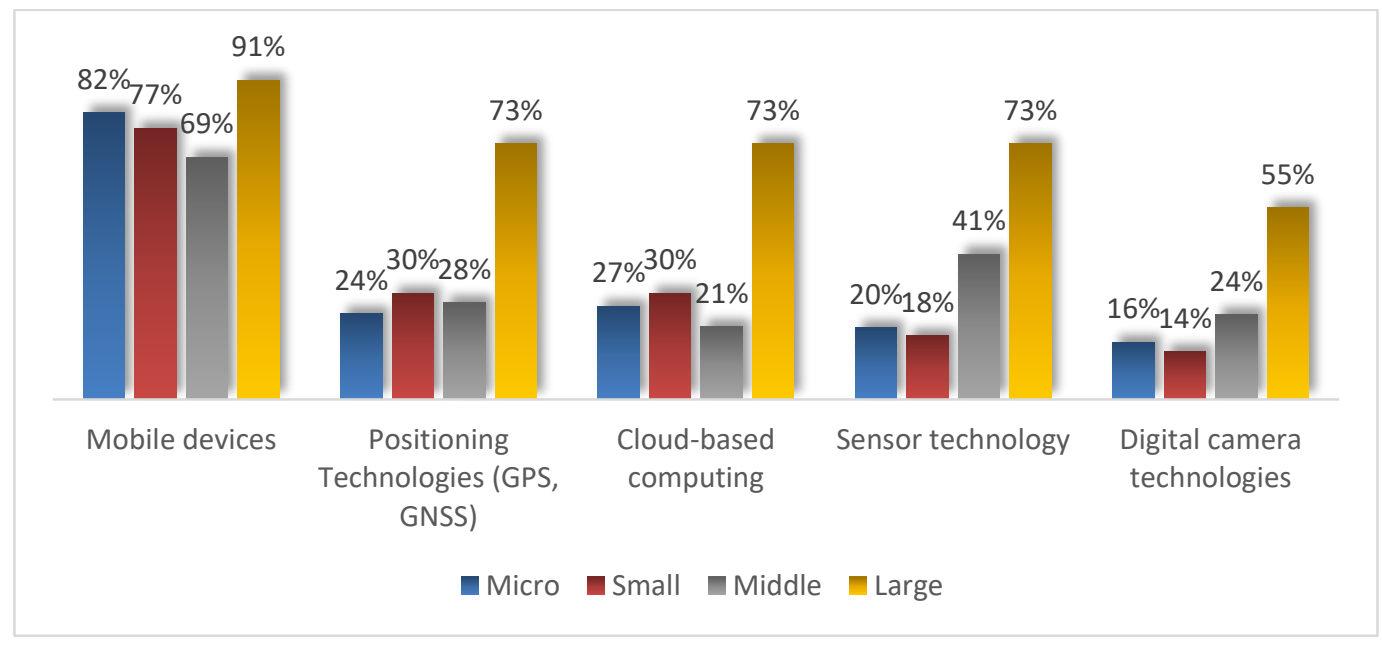

Figure 3. Enterprise-wide distribution of the top five most common digital technologies $(N=155)$ 


\begin{tabular}{|l|r|r|r|r|r|r|}
\hline Sector / Digital Technology & $\begin{array}{l}\text { Mobile } \\
\text { devices }\end{array}$ & $\begin{array}{l}\text { Location } \\
\text { technologies } \\
\text { (GPS, GNSS) }\end{array}$ & $\begin{array}{l}\text { Cloud-based } \\
\text { computing }\end{array}$ & $\begin{array}{l}\text { Sensor } \\
\text { technology }\end{array}$ & \multicolumn{2}{l}{$\begin{array}{l}\text { Digital } \\
\text { camera } \\
\text { technologies }\end{array}$} \\
\hline Meat Industry & $75 \%$ & $36 \%$ & $21 \%$ & $39 \%$ & $25 \%$ \\
\hline Processing of fruit and vegetables & $80 \%$ & $35 \%$ & $30 \%$ & $25 \%$ & $25 \%$ \\
\hline Manufacture of vegetable and animal oils & $60 \%$ & $40 \%$ & $40 \%$ & $20 \%$ & $40 \%$ \\
\hline Milk Processing & $67 \%$ & $0 \%$ & $33 \%$ & $33 \%$ & $17 \%$ \\
\hline Manufacture of grain mill products & $90 \%$ & $70 \%$ & $30 \%$ & $20 \%$ & \multicolumn{3}{|l|}{$40 \%$} \\
\hline Manufacture of bakery and farinaceous products & $82 \%$ & $14 \%$ & $18 \%$ & $11 \%$ & $7 \%$ \\
\hline Manufacture of other food products & $71 \%$ & $24 \%$ & $38 \%$ & $21 \%$ & $15 \%$ \\
\hline Production of feed & $57 \%$ & $57 \%$ & $57 \%$ & & $57 \%$ & $29 \%$ \\
\hline Beverage industry & $79 \%$ & $38 \%$ & $41 \%$ & $41 \%$ & $14 \%$ \\
\hline
\end{tabular}

Table 3. The top five most common digital technologies by branches ( $N=155)$

Location data stored in mobile devices was analyzed by a quarter of businesses, while data captured by smart devices or sensors were analysed by only $13 \%$ of businesses. This may be explained by the widespread use of data mining tools.

\subsection{Digitization as a tool for horizontal and vertical enterprise integration}

We examined the current and future level of digitalization and integration, and it can be observed that the current level of digitalization and integration cannot be said to be high in any of the company areas, but respondents are very optimistic about expectations. Improvements are expected in all areas in the next 2-3 years in terms of digitalisation and integration

Vertical integration involves, first and foremost, cooperation with partners in the supply chain and later in the supply chain, digital connectivity. In the future, $21 \%$ of respondents estimate that vertical integration will be at a high level. More than a third of companies with low levels of integration today are hoping or planning for higher levels of integration.

Horizontal integration means close, real-time connectivity and collaboration within the company. The situation is similar in this case too, with the majority of enterprises hoping/planning to improve the level of integration

Horizontal integration means close, real-time connectivity and collaboration within the company. The situation is similar in this case, too, with the majority of enterprises hoping/planning to improve the level of integration.

\subsection{Development situation plan and development plans related to the implementation of Industry 4.0}

Of the 147 responding businesses, only $11 \%$ have a digital strategy (Figure 4), which is not very good considering the rise of today's digital devices and technologies. Businesses still need further development in this area, but it is essential that the effects and opportunities of digitalisation are taken into account in strategy development. 
If we also look at how the proportion of those with a digital strategy is distributed across companies by size, Figure 4 shows that between $6 \%$ and 15\% of SMEs (approximately $9 \%$ on average) and large enterprises $36 \%$ have a digital strategy. Table 4 shows the percentage of companies that have a digital strategy in each sector.

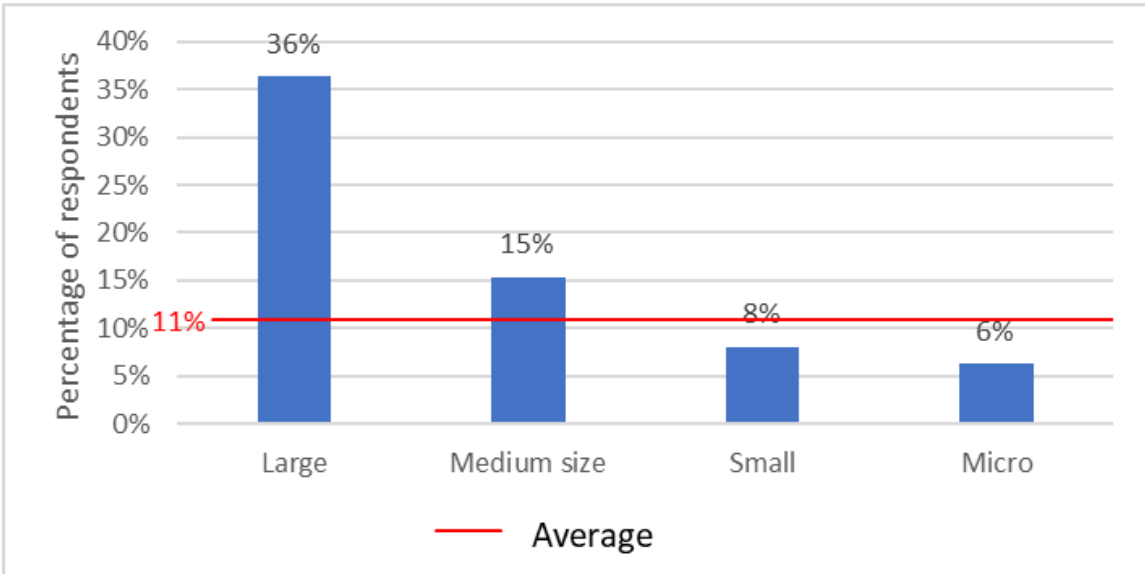

Figure 4. The proportion of companies having a digital strategy within the size category $(N=147)$

\begin{tabular}{|l|r|r|r|r|}
\hline \multicolumn{1}{|c|}{ Branch } & Have digital strategy & $\begin{array}{c}\text { Number of } \\
\text { respondents }\end{array}$ & $\begin{array}{l}\text { Proportion of having } \\
\text { digital strategy }\end{array}$ \\
\hline Oil production & 1 & 5 & $20 \%$ \\
\hline Other food & 5 & 33 & $15 \%$ \\
\hline Fruit Vegetable & 3 & 20 & $15 \%$ \\
\hline Beverage industry & 27 & $15 \%$ \\
\hline Forage & 4 & 7 & $14 \%$ \\
\hline Meat processing & 1 & 24 & $8 \%$ \\
\hline Milk Processing & 2 & 5 & $0 \%$ \\
\hline Mill product & 0 & 10 & $0 \%$ \\
\hline Pastries, pasta & 0 & 28 & $0 \%$ \\
\hline
\end{tabular}

Table 4. The proportion of having digital strategy by sectors

Digital transformation cannot be achieved without proper digital development in all areas of enterprise operations. We also looked at past and future investments, with the help of the companies participating in the survey.

Respondents in the food industry have preferred the production and manufacturing process, and this will not be different in the future. Most of the investment was probably in machinery and equipment, and further investments are planned in this direction. Logistics and sales are not far behind in terms of investments made, but R\&D is receiving less attention than other areas, with $71 \%$ of respondents investing in this area. In the next 2-3 years, 76-86 \% of respondents are planning to invest in these areas of business.

If we look only at some level of investment over the past two years, then Figure 5 shows that $8 \%$ of businesses have not invested in any area of their business, and that rate will increase by two percentage points over the next 2-3 years to grow. 
PAST 2 YEARS

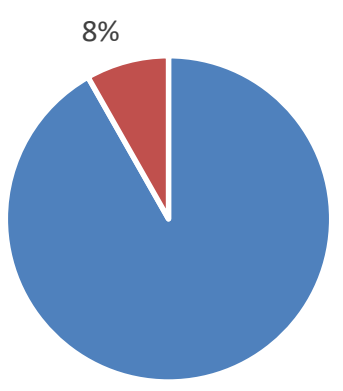

$92 \%$
IN THE NEXT 2-3 YEARS

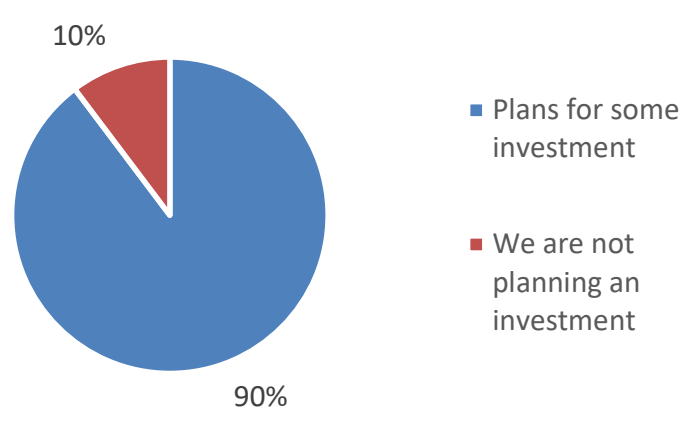

Figure 5. Status of investments made / planned for Industry $4.0(N=146)$

The benefits of digitizing a business were rated on a 1-5 scale by responding companies (1-None, 2Small, 3-Don't Know, 4-Moderate, 5-Significant). According to the answers (Figure 6), the most significant benefit is expected in terms of cost reduction $(18 \%)$, although competitiveness growth (17\%), labor efficiency (17\%) and productivity (16\%) are not far behind. Least significant revenue growth is expected (12\%).

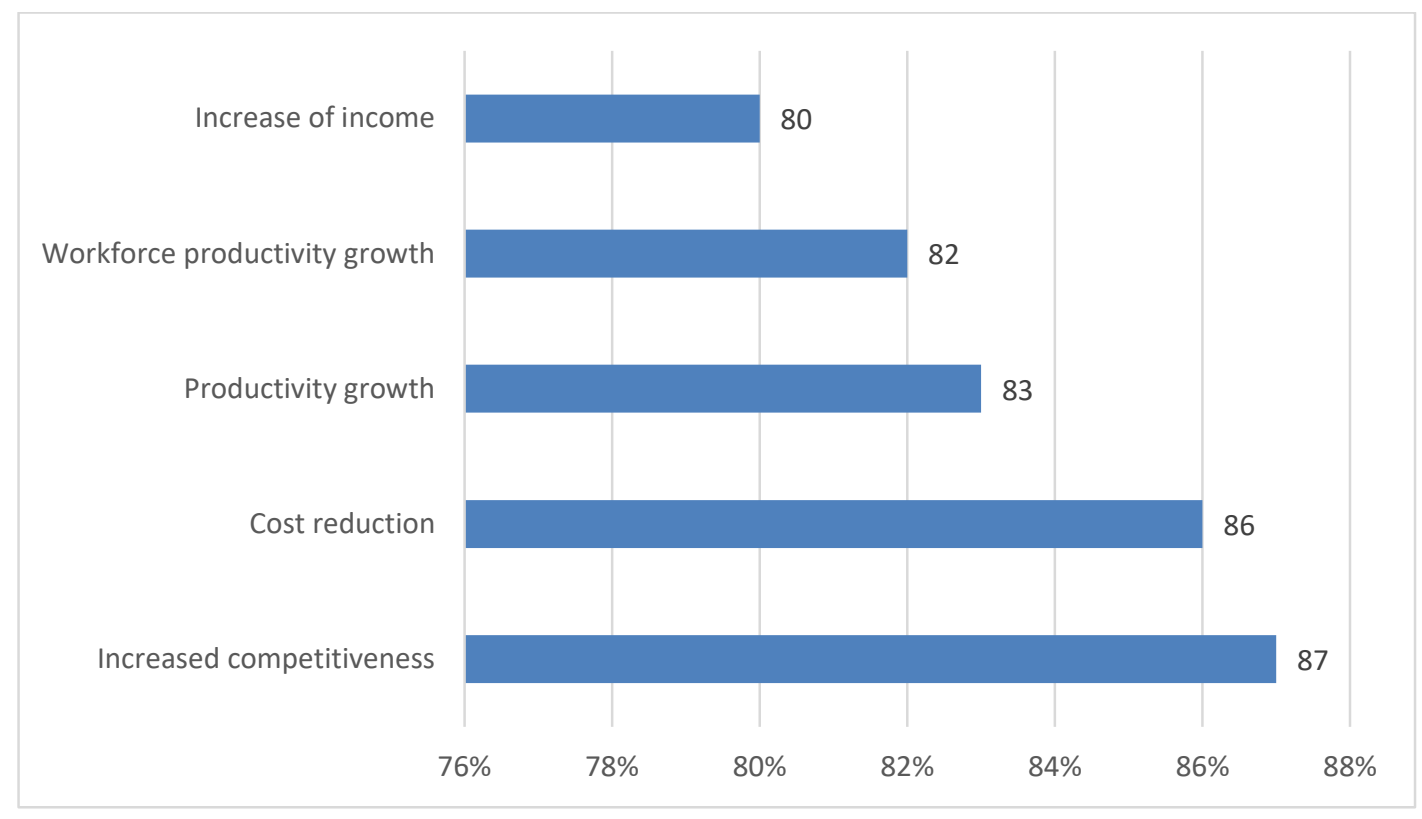

Figure 6. Estimate benefits of digitization over the next 5 years ( $N=146)$

If we look at the areas where any benefits are expected, then competitiveness will increase first (87\% of respondents expect some benefits), followed by a slight fall in costs (86\%). However, revenue growth deserves the last place in this illumination (80\%).

\section{Conclusions and further research}

IT systems not widely spread in the food manufacturing sector. The small and the micro-enterprises represented themselves in significant numbers. Generally, there is a lack of financial resources for development. 
The most important technologies are mobile devices apps, geolocation technologies, cloud-based computing, sensor technologies and using a digital camera. But using these technologies is differs according to the sizes of enterprises. There is no large difference in using mobile devices, bat there are large differences in using geolocation technologies, cloud computing and sensor technologies. In this case the difference $40 \%$. Using the ICT technologies in vertical and horizontal integration is very low and only $21 \%$ of the respondents will increase in the future.

Further research is needed. The plan is to develop evaluation model for comparison the braches using indicators and indexes (Bases on Digital Economy Metrics, Digital Density Index, Digital Economy, and Society Index, Digital Industry Metrics, Digital Enterprise Metrics) and of course, we need more advanced analysis to get more information about what is the bottleneck in digitalisation.

\section{References}

[1] M. Bombaywala - A. Riandita (2015) Stakeholders Collaboration on Innovation in Food Industry, Procedia - Social and Behavioral Sciences, Volume 169, 395-399.

[2] Sz. Botos - J. Felföldi - L. Várallyai - Á. Péntek - R. Szilágyi (2018) Analysis the advanced ICT usage if the Hungarian SME sector for preapering domestic agri-food research. APSTRACT Applied Studies in Agrobusiness and Commerce 11: 3-4, 147-154.

[3] M. Demartini - C. Pinna - F. Tonelli - S. Terzi - C. Sansone - C. Testa (2018) Food industry digitalization: from challenges and trends to opportunities and solutions, IFAC-PapersOnLine, Volume 51, Issue 11, 1371-1378.

[4] I. Füzesi - J. Felföldi - J. Pancsira - P. Lengyel (2019) Analysis of the implementation of blockchain-based traceability systems. Journal of Ecoagritourism 15:1, 34-39.

[5] I. Füzesi - J. Felföldi - A. Csordás - P. Lengyel (2018) Analysis of application of ERP systems at hungarian meat companies. Journal of Ecoagritourism $14: 1,23-28$.

[6] P. Gimenez-Escalante - S. Rahimifard (2019) Metrics for identifying the most suitable strategy for distributed localised food manufacturing, Procedia Manufacturing, Volume 33, 586-593.

[7] L. Heiner - P. Fettke - H.-G. Kemper - T. Feld and M. Hoffmann (2014) Industry 4.0., Business \& Information Systems Engineering 6, no. 4, 239-242.

[8] K. Henning - J. Helbig - A. Hellinger and W. Wahlster (2013) Recommendations for implementing the strategic initiative INDUSTRIE 4.0: Securing the future of German manufacturing industry; Final report of the Industrie 4.0 Working Group. Forschungsunion.

[9] Z. H. Khan - A. Khalid - J. Iqbal (2018) Towards realizing robotic potential in future intelligent food manufacturing systems, Innovative Food Science \& Emerging Technologies, Volume 48, 11-24.

[10] J. Lee - B. Bagheri and H.A. Kao (2015) A cyber-physical systemsarchitecture for industry 4.0based manufacturing systems. Manufacturing Letters, 3, 18-23. 
[11] E. Manavalan - K. Jayakrishna (2019) A review of Internet of Things (IoT) embedded sustainable supply chain for industry 4.0 requirements, Computers \& Industrial Engineering, Volume 127, 925-953.

[12] Marsh (2017) Food Manufacturing-Are You Ready for Industry 4.0?, Marsh Report, 2017, https://www.marsh.com/content/dam/marsh/Documents/PDF/UK-en/

[13] J. Miranda - P. Ponce - A. Molina - P. Wright (2019) Sensing, smart and sustainable technologies for Agri-Food 4.0, Computers in Industry, Volume 108, 21-36.

[14] M. F. Mogos - R. J. Eleftheriadis - O. Myklebust (2019) Enablers and inhibitors of Industry 4.0: results from a survey of industrial companies in Norway, Procedia CIRP, Volume 81, 624629.

[15] M. R. Nichols (2018) How Industry 4.0 Will Effect the Food and Beverage Industry, http://industrytoday.com

[16] N. Ourania - V. Aspasia (2015) Marketing Responses of Greek Food Manufacturing Firms due to Economic Crisis, Procedia - Social and Behavioral Sciences, Volume 175, 350-357.

[17] L. Pusztai - B. Kocsi - I. Budai (2017) Business process development with the application of simulation technique, International Journal of Engineering and Management Sciences / Műszaki És Menedzsment Tudományi Közlemények 2 : 3, 109-118.

[18] L. Pusztai - B. Kocsi - I. Budai (2019) Making engineering projects more thoughtful with the use of fuzzy value-based project planning, Pollack Periodica: An International Journal for Engineering and Information Sciences 14 : 1, 25-34.

[19] S. Rahmat - C. Boon C. - M. S. R. B. A. Hamid (2016) Challenges of Developing Countries in Complying Quality and Enhancing Standards in Food Industries, Procedia - Social and Behavioral Sciences, Volume 224, 445-451.

[20] E. Rauch - M. Unterhofer, P. Dallasega (2018) Industry sector analysis for the application of additive manufacturing in smart and distributed manufacturing systems, Manufacturing Letters, Volume 15, Part B, 126-131.

[21] F. Tektüfekci (2019) A Bibliometric Analysis of Industry 4.0-Focused Turkish E-Accounting Applications, Procedia Computer Science, Volume 158, 602-608.

[22] T. Tokody (2018) Digitising the European industry - holonic systems approach, Procedia Manufacturing, Volume 22, 1015-1022.

[23] S. Wolfert - C.N. Verdouw - C.M. Verloop - AJM. Beulens (2010) Organizing information integration in agri-food - A method based on a service-oriented architecture and living lab approach, Computers and Electronics in Agriculture, Vol. 70, 389-405.

[24] L-W. Wong - L-Y. Leong - J-J. Hew - G.W-H. Tan - K-B. Ooi (2019) Time to seize the digital evolution: Adoption of blockchain in operations and supply chain management among Malaysian SMEs, International Journal of Information Management, Article in Press, https://doi.org/10.1016/j.ijinfomgt.2019.08.005. 
[25] M. Zaki - B. Theodoulidis - P. Shapira - A. Neely - E. Surekli (2017) The Role of Big Data to Facilitate Redistributed Manufacturing Using a Co-creation Lens: Patterns from Consumer Goods, Procedia CIRP, Volume 63, 680-685.

[26] W. Zhang (2012) Study on Base Management Pattern of Food Producing Enterprise, Physics Procedia, Volume 24, Part B, 1108-1113. 